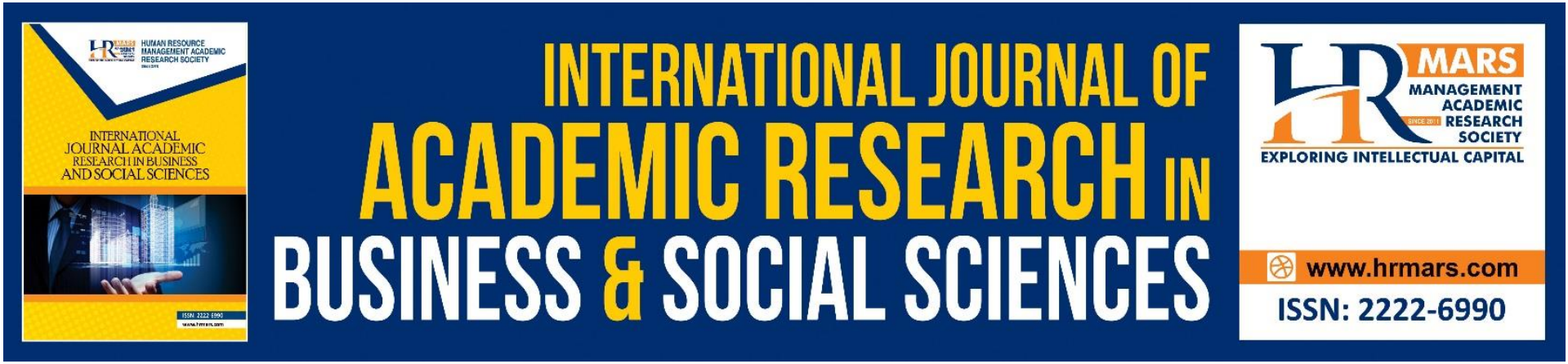

\title{
Assessing the Relationship between Hotel Restaurant Brands Attributes and Customer Satisfaction: The Mediating Role of Customer Dining Experience
}

\section{Tuan Ahmad Tuan Ismail, Dwi Suhartanto, Faizal Azrin Abdullah}

To Link this Article: http://dx.doi.org/10.6007/IJARBSS/v11-i16/11231～DOI:10.6007/IJARBSS/v11-i16/11231

Received: 05 July 2021, Revised: 10 August 2021, Accepted: 29 August 2021

Published Online: 27 September 2021

In-Text Citation: (Ismail et al., 2021)

To Cite this Article: Ismail, T. A. T., Suhartanto, D., \& Abdullah, F. A. (2021). Assessing the Relationship between Hotel Restaurant Brands Attributes and Customer Satisfaction: The Mediating Role of Customer Dining Experience. International Journal of Academic Research in Business and Social Sciences, 11(9), 232-243.

Copyright: (c) 2021 The Author(s)

Published by Human Resource Management Academic Research Society (www.hrmars.com)

This article is published under the Creative Commons Attribution (CC BY 4.0) license. Anyone may reproduce, distribute, translate and create derivative works of this article (for both commercial and non-commercial purposes), subject to full attribution to the original publication and authors. The full terms of this license may be seen at: http://creativecommons.org/licences/by/4.0/legalcode

Special Issue Title: Contemporary Issues in Tourism and Hospitality industry, 2021, Pg. 232 - 243

Full Terms \& Conditions of access and use can be found at http://hrmars.com/index.php/pages/detail/publication-ethics 


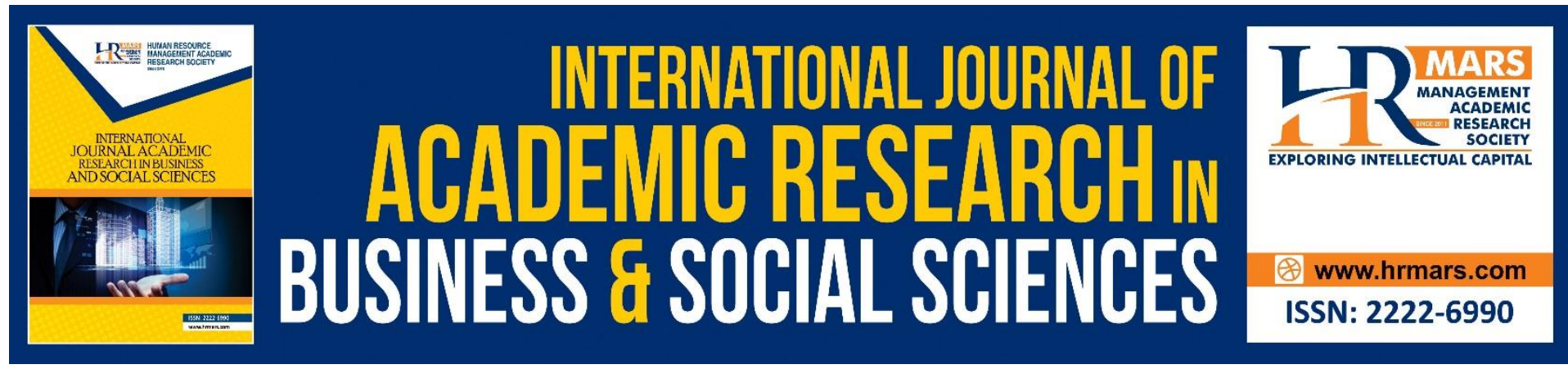

\title{
Assessing the Relationship between Hotel Restaurant Brands Attributes and Customer Satisfaction: The Mediating Role of Customer Dining Experience
}

\section{Tuan Ahmad Tuan Ismail'1, Dwi Suhartanto², Faizal Azrin} Abdullah $^{1}$

${ }^{1}$ Faculty of Hotel and Tourism Management, Universiti Teknologi MARA, Puncak Alam Campus, Selangor, Malaysia, ${ }^{2}$ Department of Business Administration, Politeknik Negeri

Bandung, Jl. Gegerkalong Hilir, Ds., Ciwaruga Bandung Jawa Barat, Indonesia

Email: tuana436@uitm.edu.my

\begin{abstract}
Experience in the context of business has become a part of important attributes especially in the service marketing segment. According to experts, shaping and designing customer experience is part of the experience economy. In a similar vein, experience is built once the customers get to know a product or service through the brand, use its facilities, and experience it. The importance of brand is without exception and it is also associated with the restaurant industry. That is the reason why creating a strong brand is one of the strategies used by many independent and hotel restaurant marketers in attracting and retaining customers for its performance and operational survival. The concepts of brand loyalty, awareness, brand image and brand competitiveness have gained many interests among researchers in general restaurant setting and operational aspects. However, research that specifically looks at the relationship between customer restaurant experience, particularly dining experience in the hotel restaurant setting, is still sparse and overlooked. A quantitative method was used in this study with hotel restaurant customers who dined at the restaurant as samples of investigation. In this study, dining experience is positioned as a mediating variable to see its effect between hotel restaurant brand attributes and customer satisfaction. The results revealed no significant mediating effect of dining experience towards hotel restaurant brand attributes and customer satisfaction.
\end{abstract}

Keywords: Customer Experience, Dining, Restaurant Brand, Satisfaction

\section{Introduction}

Since the hotel industry, just like other industries, is considered as an experienced-based service industry (Gilmore \& Pine, 2011; Ismail et al., 2016), previous service experience has been proven to be an important indicator for customers when making re-selection and purchasing decisions on hotel brands (Ren et al., 2016). Customer satisfaction with the whole service brand experience has also been shown to influence post-purchase behaviour intention 
(Clemes et al., 2011; Cronin et al., 2000; Chen \& Chen, 2010; Zins, 2002). Cass and Grace (2004) stated that customer's experience with a company had a significant impact on service brand, and that experience is an important criterion for customers when deciding which service brand to buy (Keller, 1998). In fact, customer experience is crucial in developing a strong brand, and a consistent customer experience with a service brand will add value to the service brand's features (So et al., 2013).

Without doubt, the road towards a better understanding of service brands can help customers feel more confident in their purchasing decisions. However, in the context of hotel operations with other service operations, brands cannot be judged solely on the basis of their general reputable name and overall services provided. This is because it deals with many facets of services, the details of its services and attributes, such as front desk service encounters, housekeeping services, and restaurant dining service experience, which should be holistically investigated. This is supported by many studies on hotel branding which centered on the concepts of brand image (Lassar et al., 1995; O'Neill \& Mattila, 2010), brand awareness (Prasad \& Dev, 2000; Kim et al., 2009), brand loyalty (Dyson et al., 1996; Suhartanto, 2011) perceived quality in relation to brand perception (Yoo \& Donthu, 2005; Kayaman \& Arasli, 2007; Aaker, 1991,1996; Hussein et al., 2018), brand performance (Lassar et al., 1995; Prasad \& Dev, 2000) and brand competitiveness (Simon \& Sullivan, 1993; Cai \& Hobson, 2004) with still little attention given on the relation between service brand attributes and customer experience. Many observers emphasized that service brands should be examined from a marketing perspective and for their included features in relation to customer experience and the dimensions offered in the hotel restaurant context (Berry, 2000; Kim \& Kim, 2005).

Muller and Woods (1998) posited that besides maintaining excellent food and service, building a restaurant brand is also becoming a primary objective for most restaurant managers. In fact, food quality and service quality in so many years have become a pillar and act as catalyst in building and establishing restaurant brands (Nield et al., 2000). From the context of service quality, Ladhari et al. (2008) explained that service quality is the antecedent of customer experience while satisfaction is the consequence of dining experience. In particular, many scholars contended that hotel restaurant brand attributes which consist of food, services and physical environment act as a bundle and cannot be looked like a single element. In fact, this bundle influences restaurant dining experience and is an indicator for establishing a level of satisfaction and post dining intention (Rust et al., 2005; Paswan et al., 2007). This concept and circumstance are likely to fit those who choose and always stay in a specific hotel since they have made up their minds to be there from the start, and they are also likely to be affordable due to the hotel's overall branding or image, including its food and beverage outlets. This scenario may alter for walk-in customers, since their decision to dine at a specific hotel restaurant may be based on a variety of factors such as business, pleasure, and others. Despite this, and closely related to this study, the question involved is whether a customer's dining experience at a hotel restaurant as measured by cuisine, services, and physical surroundings influences a walk-in customer's decision to dine at that particular hotel restaurant. 


\section{Literature Review \\ Dining Experience}

In terms of customers' dining experience, there is no doubt that this practice stimulates customer loyalty by eliciting positive emotion during the dining process (Arora, 2006). A common feature for a pleasant eating experience in a restaurant has always been acknowledged, including high-quality cuisine, excellent service, pleasing ambiance, and other facilities. All of them are interconnected and considered restaurant branding (Lockyer, 2005). For example, low quality service does not imply that consumers will not be loyal if the food is of high quality, and vice versa. In other circumstances, customers are ready to wait a little longer when the service is little delayed if the cuisine is superb and the physical setting is pleasant. As a result of this interconnected characteristic, high-quality cuisine and good service have become the basic components, but it is not the "punchline" for restaurant operators to entice customers. However, it will be much more divine if all of the above features are accomplished through restaurant brands that are consistent with hotel branding.

A restaurant can give a competitive edge for its operation by offering the customer an experience in food and beverage as the second source of income in hotel services, in addition to rooms and other facilities (Siguaw \& Enz, 1999; Rutherford, 2002). As it deals with social and economic factors, dining experience in a restaurant can be gained with leisure, pleasure, and requirements (Warde \& Martens, 2000). According to Lachat et al. (2012), the growing popularity of eating out is due to busy lifestyles, insufficient time to prepare home cooked meals, media exposure (celebrity chefs, food innovation), and the increasing number of new food outlets which influences customers dining experiences at a specific restaurant. Arora (2006) claimed that as customers get more educated, they desire an 'enthusiastic experience' and joy experience rather than time-saving (eat-on-the-run) concept when it comes to dining out. Hence, restaurants are competing with one another to attract clients through varied experiences in order to keep up with the shifting trend of customer consumption habits in relation to meal eating patterns (Mikela, 2000).

Based on the literature, scholars use many terms in relation to dining experience in the restaurant perspective. Meal experience, eating out experience, restaurant experience, quality food and service experience are the obvious terms used interchangeably and some of them divided these experiences into two which are tangible and intangible experience (Andersson \& Mossberg, 2004; Gustafsson et al., 2006; Hanefors \& Mossberg, 2003).

\section{Hotel Restaurant Brand}

Before proceeding into a detailed review, it is worth mentioning that despite different terms of name (hotel restaurant brand and independent restaurant brand), they share the same brand attributes. Since lack of literature is specifically related to hotel restaurant brands per se; therefore, this section mostly reviews the brand from independent restaurant perspectives. In the past, the inclination of customers to dine at any restaurant was well dependent on the functional value of food and services that operators provided. Taste, variety of food, freshly prepared food and quick service are the attributes that clearly affect the customers' inclination toward patronization. In consensus, if the restaurateur is able to provide and maintain those elements, they would stay longer and be more resilient in the operation (Othman et al., 2013). However, with the waves of modernization and customers have hastily adapted with the changing of lifestyle, inadequate time to prepare home cook 
food, the growing interest in cuisines, media exposure (celebrity chefs, food innovation), the increasing growth of restaurants in many businesses areas (shopping center, high streets), higher educational level and increase of disposable income, they are no longer focusing on functional value alone when making a decision in choosing the restaurant and purchasing products/services (Bhatti et al., 2011). In line with these contributory factors and the changing pace, many consumers are now interested and turning into brands when dining at a restaurant (Baek et al., 2010; Dubois \& Czellar, 2002). In other words, restaurant brand is becoming one of the criteria in selecting the restaurant and the increase of such customers or popularly known as brand seekers is rather obvious in the present days (Vigneron \& Johnson, 1999).

It is clear that when establishing a distinct brand among restaurateurs and restaurants, the manager is a top priority (Muller \& Woods, 1998). Many restaurateurs are changing their corporate missions to reflect branding orientation rather than product orientation, and restaurant managers are observed to implement brand management theories and techniques. According to Muller and Woods (1998), the restaurant industry exhibits characteristics on the decline stage of the product life cycle, necessitating the adoption of brand management abilities as one of their key competences in order to stay in business and remain competitive in the marketplace. According to the proposition that a brand is in the consumer's memory and the future of the product is clearly dependent on it, restaurateurs and restaurant managers should place a high priority in adopting a brand orientation (Kapferer, 1997) and developing and maintaining high-quality brands with positive associations (Aaker, 1996). In line with this, Kim and Kim (2005) and Jin et al. (2012) proposed that physical environment is one of the components of restaurant brand attributes in addition to food and services.

\section{Customer Satisfaction}

Customer satisfaction is defined as the pleasant feeling a customer gets from a desirable product as a result of a process or an outcome (Vavra, 1997). According to Oliver (1981), customer satisfaction is defined as "a purchaser's fulfilment reaction and a decision that a product or service feature, or service itself, provided (or is providing) a pleasant level of consumption-related fulfilment, including levels of under or over fulfilment as being consistent with the conceptual and empirical evidence". Customer satisfaction, according to Lovelock (2010), is "an attitude-like judgement following the customer experience, with the confirmation or disconfirmation of pre-consumption expectations as its primary determinants." Customer satisfaction is measured using hotel and restaurant brand features in this study.

Customers are more likely to patronise restaurants again if the total eating experience meets their expectations (Kandampully \& Suhartanto, 2000). Food, service, and the working atmosphere are among them. According to Adebanjo (2001), understanding customer satisfaction in the restaurant industry is crucial for business survival. This understanding would help restaurant operators build up their basic building block to better understand customer satisfaction. He further claimed that while there is no certainty that satisfied consumers will return, unsatisfied customers are almost certain not to. According to Barlow and Møller (1996), keeping guests satisfied through cuisine and excellent service is critical for hotel restaurants to produce money. He argued that to attain a high degree of customer 
satisfaction in the restaurant industry, the restaurant management must ensure that the customer's expectations for their product and service are met or exceeded. As a result, managers must understand customer satisfaction and service demand in order to meet customers' expectations for total eating experiences, which is similar in the food service industry.

Félix-Brasdefer (2015) emphasized the importance of employees' interactions with customers during service encounters, and he argued that bad service delivery leads to poor results. According to Sanes (1996), the role of employees in providing customer satisfaction and the methods in which management may assist and motivate them is critical because customer satisfaction is strongly tied to employee satisfaction. Customer satisfaction occurs when the customer's perception is met or exceeds the customer's expectation (Mohajerani \& Miremadi, 2012). Customer satisfaction is described as a person's view of a performance of products or services that are tailored to his or her expectations (Torres et al., 2014). In the context of cafes and restaurants, Pratten (2004) stressed the importance of waiting staff, both waiters and waitresses, in achieving customers' expectations of the services provided because customer satisfaction can be easily gained from restaurant patrons. In contrast, if restaurant owners fail to provide proper training, especially during the delivery process and the important roles of waiting staff in ensuring customer satisfaction is fulfilled, they will face a possibility of losing their business.

The current research believes that affect is a forerunner to satisfaction, and that satisfaction is the outcome of evaluating the effect gained from a consumption experience. Forgas (1995) outlined the ways in which affect might influence satisfaction through affect infusion (or affect transfer), implying those positive emotions shape what is noticed, encoded, and retrieved during the judgement process. Individuals may also estimate their overall attitude towards an object by using their affective state as a shortcut. In either instance, being able to recognize an individual's feelings at any one time is critical, as is being able to quantify evolving stages of emotions over the course of an encounter (Dubé \& Morgan, 1998).

\section{Methodology}

As this study deals with mediating variables, it is important to initially explain this variable before undertaking the test and reporting the result. According to Baron and Kenny (1986), mediating is the variable that causes intervention between the dependent and independent variables, which explains its relationship. A complete mediation process means a complete intervention caused by the mediator variable. A mediator represents unbalanced relations among research variables (MacKinnon, 2008). According to Hair et al. (2014), the mediator will indirectly affect a relationship between independent and dependent variables, and the mediator will add to the overall variance accounted for in the model. The mediator tries to explain the relationship between the independent and dependent variables (Hayes, 2013). Both approaches use the same mediation rule that is still based on the classic mediation model (Figure 1.0), in which $X$ significantly predicts $Y$ (total impact) and the indirect effect ( $a b)$ is significant. Path $c^{\prime}$ (path $c^{\prime}=c+a b$ ) can explain the mediation test. Therefore, Hayes (2013) technique was utilized to examine customer eating experience mediation effects. In recent years, standards for PLS investigations have been established (Hair et al., 2014; Nitzl et al., 2016). This method has been utilised extensively in empirical studies (Castro \& Roldán, 2013; Vega-Vázquez et al., 2016). 


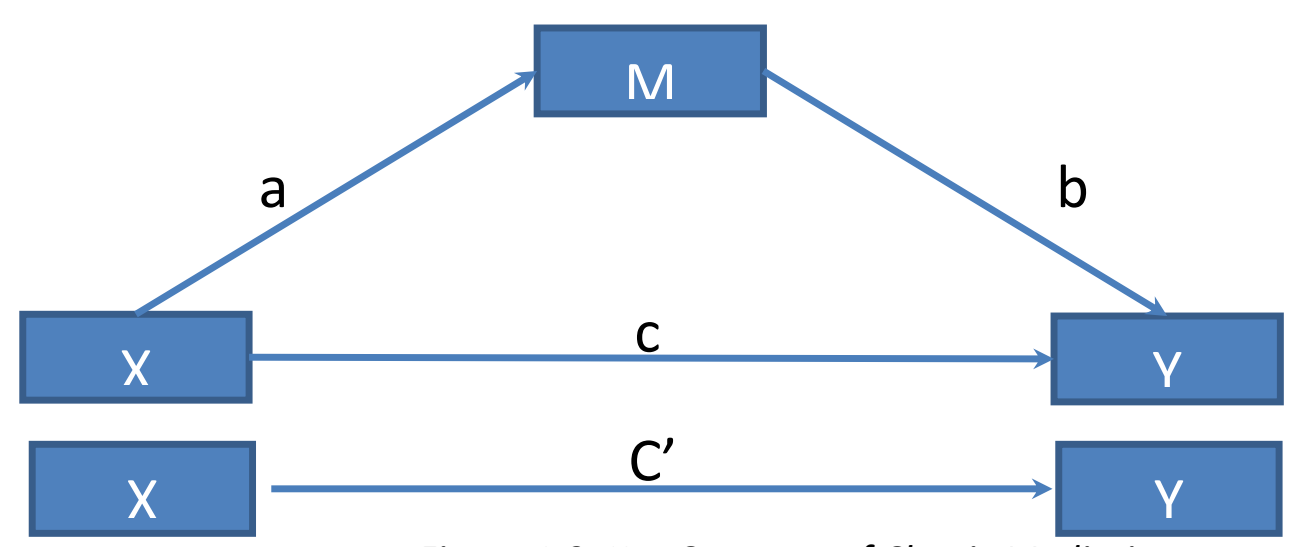

Figure 1.0: Key Concepts of Classic Mediation

\section{Result and Analysis}

The mediation analysis of Dining Experience on the relationship between Hotel Restaurant Brand Attributes (HRBA) and Walk-In Customer Satisfaction was performed through PROCESS by using 1000 bootstrap samples for bias correction to establish 95 percent confidence intervals. The results from the analysis are shown in Figure 2.0 and Table 1.0.

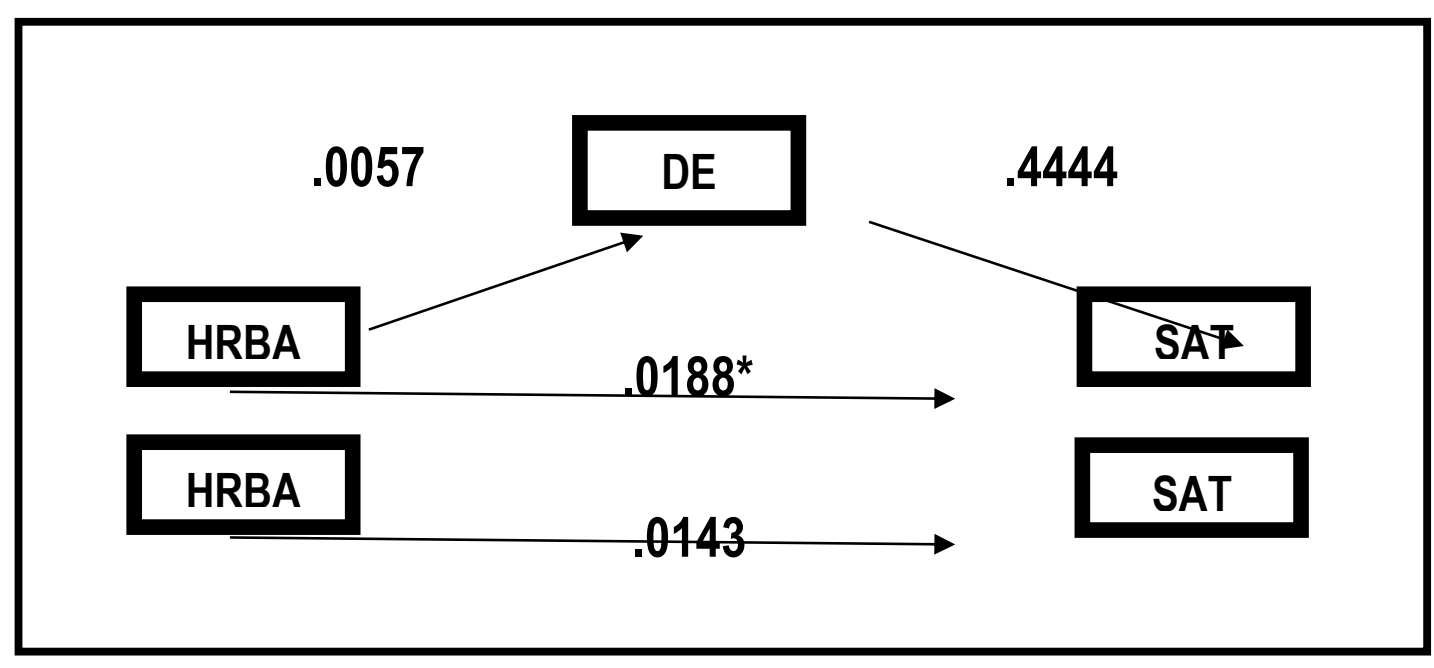

Figure 2.0: Mediation Test of Dining Experience (DE) on Hotel Restaurant Brand Attributes (HRBA) and Walk-In Customer Satisfaction (SAT)

Table 1.0

\begin{tabular}{|l|l|l|l|l|}
\hline Path & Relationship & Result & \multicolumn{2}{l|}{ Bootstrapping result } \\
\hline \multicolumn{3}{|l|}{} & LL 95 Cl & UL 95 Cl \\
\hline Path a & Effect of HRBA on DE & .0057 & -.0693 & .0807 \\
\hline Path b & Effect of DE on SAT & .4444 & .3429 & .5458 \\
\hline Path c & Effect of HRBA on SAT & $.0188^{*}$ & -.0767 & .1054 \\
\hline Path c' & $\begin{array}{l}\text { Effect of HRBA on SAT } \\
\text { mediated by DE }\end{array}$ & .0143 & -.0730 & .1054 \\
\hline
\end{tabular}

Table 1.0 suggests that the path between Hotel Restaurant Brand (HRBA) to Dining Experience (DE) was insignificant with a standardized coefficient of .0057. Furthermore, the path between Dining Experience (DE) and Customer Satisfaction (SAT) was also found not 
significant ( $\beta$ : .4444). It was also found that Dining Experience (DE) mediated the relationship between Hotel Restaurant Brand (HRBA) and Customer Satisfaction (SAT) with an indirect effect of .0143 which was not significant with an $\mathrm{R}^{2}$ of 0.0141 . All in all, the above results concluded that Dining Experience (DE) did not have a strong indirect effect on the relationship between Hotel Restaurant Brand (HRBA) and Customer Satisfaction (SAT). The finding demonstrated that there was an insignificant relationship between hotel restaurant brand attributes and walk-in customer satisfaction mediated by dining experience ( $\beta M$ : $0.041, t-$ value: 4.617). In this sense, dining experience as a mediator indirectly affected the relationship between hotel restaurant brand attributes and walk-in customer satisfaction.

What could be assumed from the overall result of this section analysis is that the impact of hotel restaurant brands attributes on walk-in customer satisfaction will not be increased or decreased with the presence of dining experience. In other words, dining experience did not increasingly or decreasingly affect the hotel restaurant brands attributes that comprise of food quality, service quality and physical environment toward walk-in customer satisfaction. In more depth, despite having tangible or personal interaction and intangible feelings during the dining period, the five-star hotel restaurant branding which is made up of food, physical surroundings, atmosphere, and services employees is still less able to uplift or maximize walkin customers' level of satisfaction. This may strengthen the notion made by Oliver (1981) which posited that customers satisfaction is subjected to change or altered depending on their consumption experience which includes the taste of food, restaurant atmosphere (Sulek \& Hensley, 2004) and service environment (Brocato \& Kleiser, 2005) of a restaurant which significantly affects or may directly influence the individual's customer satisfaction. In addition, as accentuated by Smith and Bolton (2002), and Schoefer and Ennew (2005), customers' satisfaction response towards tangible and intangible factors affects their satisfaction level and behavioural intention.

\section{Conclusion}

In conclusion, it has provided further insight into the relationship between hotel restaurant brand qualities, dining experience, and customer satisfaction. It is hoped that the findings will not only add to the existing documentation and strengthen the literature on restaurant customer behaviour. However, it will also serve as a foundation and platform for other researchers to investigate and expand it into a much broader scope, particularly in the areas of high-end restaurant branding, customer dining experience, and customer satisfaction.

\section{Acknowledgement}

This study was funded by the Ministry of Education, University Teknologi MARA, MALAYSIA.

\section{Corresponding Author}

Tuan Ahmad Tuan Ismail. Faculty of Hotel and Tourism Management, Universiti Teknologi MARA, Puncak Alam Campus, 42300, Selangor, Malaysia.

Email: tuana436@uitm.edu.my

\section{References}

Aaker. (1991). Managing brand equity: Capitalizing on the value of a brand name. New York: Maxwell Macmillan Canada.

Aaker. (1996). Building strong brands. New York: Free Press. 
Adebanjo, D. (2001). Understanding customer satisfaction - A UK food industry case study. British Food Journal, 103(1), 36-45.

Andersson, T. D., \& Mossberg, L. (2004). The dining experience: do restaurants satisfy customer needs?. Food Service Technology, 4(4), 171-177.

Arora, R. S. J. (2006). Cognitive and affective service marketing strategies for fine dining restaurant managers. Journal of Small Business Strategies, 17(1), 51.

Baek, T. H., Kim, J., \& Yu, J. H. (2010). The differential roles of brand credibility and brand prestige in consumer brand choice. Psychology \& Marketing, 27(7), 662-678.

Barlow, J., \& Møller, C. (1996). A complaint is a gift: Using customer feedback as a strategic tool. Berrett-Koehler Publishers.

Baron, R. M., \& Kenny, D. A. (1986). The moderator-mediator variable distinction in social psychological research: Conceptual, strategic, and statistical considerations. Journal of personality and social psychology, 51(6), 1173.

Berry. (2000). Cultivating service brand equity. Academy of Marketing Science Journal, 28(1), 128.

Bhatti, I., Parveen, S., \& Arshad, S. (2011). Effect of perceived corporate brand on customers' attitude towards Islamic banking. International Journal of Contemporary Business Studies, 2, 54-68.

Brocato, E. D., \& Kleiser, S. B. (2005). Influence of other customers: a scale development. In American Marketing Association, Conference Proceedings (Vol. 16, No. 1, p. 128).

Cai, L. A., \& Hobson, J. P. (2004). Making hotel brands work in a competitive environment. Journal of Vacation Marketing, 10(3), 197-208.

Cass, A. O., \& Grace, D. (2004). Exploring consumer experiences with a service brand. The Journal of Product and Brand Management, 13(4/5), 257.

Castro, I., \& Roldán, J. L. (2013). A mediation model between dimensions of social capital. International Business Review, 22(6), 1034-1050.

Chen, C. F., \& Chen, F. S. (2010). Experience quality, perceived value, satisfaction and behavioral intentions for heritage tourists. Tourism management, 31(1), 29-35.

Clemes, M. D., Gan, C., \& Ren, M. (2011). Synthesizing the effects of service quality, value, and customer satisfaction on behavioral intentions in the motel industry: An empirical analysis. Journal of Hospitality \& Tourism Research, 35(4), 530-568.

Cronin Jr, J. J., Brady, M. K., \& Hult, G. T. M. (2000). Assessing the effects of quality, value, and customer satisfaction on consumer behavioral intentions in service environments. Journal of retailing, 76(2), 193-218.

Dubé, L., \& Morgan, M. S. (1998). Capturing the dynamics of in-process consumption emotions and satisfaction in extended service transactions. International Journal of Research in Marketing, 15(4), 309-320.

Dubois, B., \& Czellar, S. (2002). Prestige brands or luxury brands? An exploratory inquiry on consumer perceptions.

Dyson, P., Farr, A., \& Hollis, N. S. (1996). Understanding, measuring, and using brand equity. Journal of Advertising Research, 36(6), 9-22.

Forgas, J. P. (1995). Mood and judgment: The affect infusion model (AIM). Psychological Bulletin, 117(1), 39.

Gustafsson, I. B., Öström, Å., Johansson, J., \& Mossberg, L. (2006). The Five Aspects Meal Model: a tool for developing meal services in restaurants. Journal of foodservice, $17(2)$, 84-93. 
Hair, J. F., Black, W. C., Babin, B. J., Anderson, R. E., \& Tatham, R. L. (2014). Pearson new international edition. Multivariate data analysis, Seventh Edition. Pearson Education Limited Harlow, Essex.

Hanefors, M., \& Mossberg, L. (2003). Searching for the extraordinary meal experience. Journal of Business and Management, 9(3), 249-270.

Hayes, A. F. (2013). Introduction to mediation, moderation, and conditional process analysis: A regression-based approach: Guilford Press.

Hussein, A. S., Hapsari, R. D. V., \& Yulianti, I. (2018). Experience quality and hotel boutique customer loyalty: Mediating role of hotel image and perceived value. Journal of Quality Assurance in Hospitality \& Tourism, 19(4), 442-459.

Ismail, T. A. T., Zahari, M. S. M., Shariff, F. M., \& Suhaimi, M. Z. (2016). Hotel restaurant brand attributes, dining experience, satisfaction and behavioral intention: Developing a study framework. Heritage, culture and society: Research agenda and best practices in the hospitality and tourism industry, 185-190.

Jin, N., Lee, S., \& Huffman, L. (2012). Impact of restaurant experience on brand image and customer loyalty: Moderating role of dining motivation. Journal of Travel \& Tourism Marketing, 29(6), 532-551.

Kandampully, J., \& Suhartanto, D. (2000). Customer loyalty in the hotel industry: the role of customer satisfaction and image. International Journal of Contemporary Hospitality Management, 12(6), 346-351.

Kapferer, J.-N. (1997). Strategic brand management: Creating and sustaining brand equity long term (2nd ed.). London; Dover, N.H.: Kogan Page.

Kayaman, R., \& Arasli, H. (2007). Customer based brand equity: Evidence from the hotel industry. Managing Service Quality: An International Journal, 17(1), 92-109.

Keller, K. L. (1998). Strategic brand management: Building, measuring and managing brand equity. Upper Saddle River, N.J.: Prentice Hall.

Kim, H. B., \& Kim, W. G. (2005). The relationship between brand equity and firms' performance in luxury hotels and chain restaurants. Tourism management, 26(4), 549560.

Kim, W. G., Ng, C. Y. N., \& Kim, Y. S. (2009). Influence of institutional DINESERV on customer satisfaction, return intention, and word-of-mouth. International Journal of Hospitality Management, 28(1), 10-17.

Lachat, C., Nago, E., Verstraeten, R., Roberfroid, D., Van Camp, J., \& Kolsteren, P. (2012). Eating out of home and its association with dietary intake: a systematic review of the evidence. Obesity Reviews, 13(4), 329-346.

Ladhari, R., Brun, I., \& Morales, M. (2008). Determinants of dining satisfaction and post-dining behavioral intentions. International Journal of Hospitality Management, 27(4), 563573.

Lassar, W., Mittal, B., \& Sharma, A. (1995). Measuring customer-based brand equity. Journal of Consumer Marketing, 12(4), 11-19.

Lockyer, T. (2005). The dining experience: Critical areas of guest satisfaction. Journal of Hospitality and Tourism Management, 12(1), 50-64.

Lovelock, B. A. (2010). Planes, trains and wheelchairs in the bush: Attitudes of people with mobility-disabilities to enhanced motorised access in remote natural settings. Tourism Management, 31(3), 357-366.

MacKinnon, D. P. (2008). Introduction to statistical mediation analysis: Routledge.

Mikela. (2000). Cultural definitions of the meal: Aspen, MD: Aspen Publishers, . 
Muller, C. C., \& Woods, R. H. (1998). An expanded restaurant typology. The Cornell Hotel and Restaurant Administration Quarterly, 35(3), 27-37. doi: 10.1016/0010-8804(94)901090

Nield, K., Kozak, M., \& LeGrys, G. (2000). The role of food service in tourist satisfaction. International Journal of Hospitality Management, 19(4), 375-384.

Nitzl, C., Roldan, J. L., \& Cepeda, G. (2016). Mediation analysis in partial least squares path modeling: Helping researchers discuss more sophisticated models. Industrial Management \& Data Systems, 119(9), 1849-1864.

Oliver. (1981). Measurement and Evaluation of Satisfaction Processes in Retail Settings. Journal of Retailing, 57(3), 25.

Othman, Z., Zahari, M. S. M., \& Radzi, S. M. (2013). Customer behavioral intention: Influence of service delivery failures and service recovery in Malay restaurants. Procedia-Social and Behavioral Sciences, 105, 115-121.

Paswan, A. K., Spears, N., \& Ganesh, G. (2007). The effects of obtaining one's preferred service brand on consumer satisfaction and brand loyalty. Journal of Services Marketing, 21, 75-87.

Gilmore, J. H., \& Pine, B. J. (Eds.). (2011). The experience economy. Boston: Harvard Business School Press.

O'Neill, J. W., \& Mattila, A. S. (2010). Hotel brand strategy. Cornell Hospitality Quarterly, 51(1), 27-34.

Prasad, K., \& Dev, C. S. (2000). Managing hotel brand equity: A customer-centric framework for assessing performance. The Cornell Hotel and Restaurant Administration Quarterly, 41(3), 22-4.

Pratten, J. D. (2004). Customer satisfaction and waiting staff. International Journal of Contemporary Hospitality Management, 16(6), 385-388.

Ren, L., Qiu, H., Wang, P., \& Lin, P. M. (2016). Exploring customer experience with budget hotels: Dimensionality and satisfaction. International Journal of Hospitality Management, 52, 13-23.

Rust, R. T., Lemon, K. N., \& Narayandas, D. (2005). Customer equity management. Pearson/Prentice Hall.

Rutherford, D. G. (2002). Palgrave Macmillan, Macmillan Publishers Ltd.

Sanes, C. (1996). Employee impact on service delivery. Management Development Review, 9(2), 15-20.

Schoefer, K., \& Ennew, C. (2005). The impact of perceived justice on consumers' emotional responses to service complaint experiences. Journal of Services Marketing, 19(5), 261270.

Siguaw, J. A., \& Enz, C. A. (1999). Best practices in food and beverage management. Cornell Hotel and Restaurant Administration Quarterly, 40(5), 50-57.

Simon, C. J., \& Sullivan, M. W. (1993). The measurement and determinants of brand equity: A financial approach. Marketing science, 12(1), 28-52.

Smith, A. K., \& Bolton, R. N. (2002). The effect of customers' emotional responses to service failures on their recovery effort evaluations and satisfaction judgments. Journal of the Academy of Marketing Science, 30(1), 5-23.

So, K. K. F., King, C., Sparks, B. A., \& Wang, Y. (2013). The influence of customer brand identification on hotel brand evaluation and loyalty development. International Journal of Hospitality Management, 34, 31-41. 
Suhartanto, D. (2011). An examination of brand loyalty in the Indonesian hotel industry (Doctoral dissertation, Lincoln University).

Sulek, J. M., \& Hensley, R. L. (2004). The relative importance of food, atmosphere, and fairness of wait: The case of a full-service restaurant. Cornell Hotel and Restaurant Administration Quarterly, 45(3), 235-247.

Vavra, T. G. (1997). Improving your measurement of customer satisfaction: A guide to creating, conducting, analyzing, and reporting customer satisfaction measurement programs. ASQ quality press.

Vega-Vázquez, M., Cossío-Silva, F. J., \& Revilla-Camacho, M. Á. (2016). Entrepreneurial orientation-hotel performance: Has market orientation anything to say?. Journal of Business Research, 69(11), 5089-5094.

Vigneron, F., \& Johnson, L. W. (1999). A review and a conceptual framework of prestigeseeking consumer behavior. Academy of Marketing Science Review, 1.

Warde, A., \& Martens, L. (2000). Eating out: Social differentiation, consumption and pleasure. Cambridge University Press.

Yoo, B., \& Donthu, N. (2005). The effect of personal cultural orientation on consumer ethnocentrism: Evaluations and behaviors of US consumers toward Japanese products. Journal of International Consumer Marketing, 18(1-2), 7-44.

Zins, A. (2002). Consumption emotions, experience quality and satisfaction. Journal of Travel \& Tourism Marketing, 12(2/3), 3-18.

Mohajerani, P., \& Miremadi, A. (2012). Customer satisfaction modeling in hotel industry: A case study of Kish Island in Iran. International Journal of Marketing Studies, 4(3), 134.

Félix-Brasdefer, J. C. (2015). The language of service encounters. Cambridge University Press.

Torres, E. N., Fu, X., \& Lehto, X. (2014). Examining key drivers of customer delight in a hotel experience: A cross-cultural perspective. International Journal of Hospitality Management, 36, 255-262. 